\title{
Role of Coronavirus Outbreak on Adoption of Electronic Education in New Bussa, Niger State, Nigeria
}

\author{
Joseph O. ADIGUN \\ Department of Computer Science, Federal College of Wildlife Management, New Bussa, Niger State, Nigeria \\ E-mail: sunkanmisegun@gmail.com
}

\section{Eric A. IRUNOKHAI}

Department of Computer Science, Federal College of Wildlife Management, New Bussa, Niger State, Nigeria

Oluwafemi A. ADENIJI

Department of Forestry Technology, Federal College of Wildlife Management, New Bussa, Niger State, Nigeria

Yetunde M. AREO

Department of Vocational Studies, Federal College of Forestry, Jericho, Ibadan

\section{John O. ONIHUNWA}

Department of Computer Science, Federal College of Wildlife Management, New Bussa, Niger State, Nigeria

\section{Yusuf A. SADA}

Department of Computer Science, Federal College of Wildlife Management, New Bussa, Niger State, Nigeria

\section{Caleb A. JEJE}

Department of Computer Science, Federal College of Wildlife Management, New Bussa, Niger State, Nigeria

Received: 12 March 2021; Accepted: 04 July 2021; Published: 08 October 2021

\begin{abstract}
This study was carried out in New Bussa, Niger state, Nigeria to test the infallibility of the contention that coronavirus outbreak and suspension of physical educational services that accompanies its outbreak will positively or negatively affect demand for and adoption of electronic education (e-education) by students of various educational institutions in Nigeria. The study adopted an online survey made available via Google form to residents of the study area. Furthermore the online survey was accompanied by personal interview of school administrators and tertiary institution students. The survey questionnaire was made accessible to participants that were encouraged to fill the questionnaire online between $18^{\text {th }}$ of October and $10^{\text {th }}$ of November, 2020. The data retrieved were analysed using descriptive statistics and t-test. It was found that demand for and adoption of e-education through software resources was not significantly affected by coronavirus outbreak $\left(\mu_{\text {during }}=3.90, \mu_{\text {before }}=3.72, p>0.05\right)$, while e-education through radio and television broadcast was found to be significantly affected by coronavirus outbreak $\left(\mu_{\text {during }}=4.83, \mu_{\text {before }}=4.53\right.$, $\mathrm{p}<0.05$ ). Level of income (as such, high cost of data) was found to have effect on demand for and adoption of eeducation software resources. Furthermore, social media channels and generalised software applications (with reduced or no cost of data) were found to be the most adopted software resources at the expense of proprietary e-education software resources. It is therefore recommended that Nigerian government should find a way to reduce internet access cost to enable effective adoption of electronic education through mobile and website applications.
\end{abstract}

Index Terms: Coronavirus, Electronic Education, Radio and Television Broadcast, Software Resources, Website, Social Media

\section{Introduction}

The proliferation of mobile applications, mobile devices with wireless capabilities, increasing access to the internet and reduction in the cost of internet access has enabled mobile systems to find increasing applicability [1]. Mobile software applications have therefore been applied to many fields that the traditional computing systems have found 
applications. One of such application is electronic education. Electronic education (e-education) refers to delivery of learning, training, or educational program that is supported by electronic means or simply through information communication technology (ICTs), it involves the use of varying information communication technologies including radio and television, mobile or stationary computing devices, computer network and internet in some way to provide or support training, educational or instructional material [2,3]. Different abbreviations have been used as synonyms to eeducation like electronic learning (e-learning), CBT (Computer-Based Training), WBT (Web-Based Training) and IBT (Internet-Based Training). All over the world, electronic education is being adopted to support many aspects of education through various software and hardware resources though applications such as computer aided instruction, instruction recordings, provisioning of assistive technology for the disabled, delivery of learning, training, or educational program by electronic means computer network and internet in some way to provide or support training, educational or instructional material using myriads of computing devices $[2,4]$.

The lockdown imposed by coronavirus (COVID 19) pandemic which started towards the end of 2019 increased the level of adoption of electronic education in many developed countries. For education actors such as teachers, proprietors, education ministry, the covid-19 became a challenge whose solution requires approach that has no predocumented guide. This is because as the number of COVID-19 cases started increasing worldwide, governments of many nations started implementing measures that limit the number of people gathering together in public places. Such measures interrupted normal functioning of schools at various levels from primary to universities, meanwhile discontinuity in education has adverse effects on the students, the parents and the nation as a whole. Meanwhile, persistence increase in number of cases continues to extend the educational lockdown thus enforcing the need for educational actors to find alternative methods for students and teachers to continue with their lessons ubiquitously and virtually to abide by the lockdown imposed by government while at the same time afford the students to go on with their educational studies. Thus, every country sees electronic education as a way to go to afford the students and teachers continuous, ubiquitous and virtual teaching-learning experience during the lockdown.

In developing countries such as Nigeria, several researches including $[5,6,7]$ were carried out to ascertain the impacts of coronavirus on level of adoption of e-education, however, their findings was inconclusive. This necessitates the need to carry out a study to ascertain whether or not coronavirus impacts on the adoption of electronic education in Nigeria which is the essence of this study.

\subsection{Purpose of study}

The aim of the study is to assess the role of coronavirus outbreak on adoption of electronic education in New Bussa, Niger State, Nigeria. The objectives of this study are:

- To examine the difference in adoption of electronic education software resources before and during coronavirus pandemic

- To analyse the difference in adoption of electronic education through radio/television broadcast before and during coronavirus pandemic

- To ascertain the difference between adoption of software resources and radio/television broadcast for electronic education before coronavirus pandemic in the study area

- To ascertain the difference between adoption of software resources and radio/television broadcast for electronic education during coronavirus pandemic in the study area

- To determine the influence of income on the adoption of electronic education software in the study area

\subsection{Research Hypotheses}

Based on the itemised objectives, the study was guided by the following research hypotheses.

- $\mathrm{H}_{0} 1$ : There is no significant difference between adoption of electronic education software resources during coronavirus outbreak

- $\mathrm{H}_{0}$ 2: There is no significant difference between adoption of electronic education radio/television broadcast before and during coronavirus outbreak

- $\mathrm{H}_{0} 3$ : There is no significant difference between adoption of electronic education software resources and radio/television broadcast before coronavirus outbreak

- $\mathrm{H}_{0} 4$ : There is no significant difference between adoption of electronic education software resources and radio/television broadcast during coronavirus outbreak

- $\mathrm{H}_{0}$ 5: Individuals' income will not significantly affect adoption of e-education 


\section{Previous Studies}

Electronic education is not a new technology. Some situations have necessitated the need for electronic education in time past, they include the need for eradicating educational marginalization of the disabled population [3], need for distance education [9], need for distance examination [9, 10], need for computer aided differentiated instruction [11], need for lecturers' evaluation and appraisal system [12] among others. Recently, the lockdown enforced by the corona virus pandemic has further compelled the need to better integrate electronic education. In late 2020, corona virus disease (COVID-19) probably of bat origin was imported to the human population in Wuhan, China in the last days of 2019 [13]. The disease later proved itself as the most highly infectious disease [14] whose confirmed cases exceeded those of severe acute respiratory syndrome (SARS) and Middle East respiratory syndrome (MERS) such that within three and half months, confirmed cases of COVID-19 had exceeded 1,800,000 cases and 117,000 fatalities [15]. The virus spread almost across all countries of the world both developed and developing with the developed worst hit with fatalities. Thus, stay at home measure was imposed in many parts of the world and this necessitate the need for electronic education if teaching and learning would continue.

Due to the necessity of adoption of electronic education imposed by COVID-19, the education divide between the developed and developing countries seems to be widening further. This is because while many educational institutions in the developed countries especially in Europe and Americas have adopted e-education to a considerable level, many institutions of learning in the developing countries (especially in Africa) have not gone beyond the level of pilot testing e-education. From the optimistic point of view however, the necessity of adopting e-education brought about by COVID-19 pandemic amount to a serious incentive to reform African education and Covid-19 which will add to the pressure of stepping up e-education [16]. As one survey participant from Liberia in [16] put it, the "Covid-19 crisis has only pointed out the weakness in the educational sector of the country. Efforts to respond now by providing digital solutions must be long term and sustained. The future of work in the world demands this and countries like Liberia would soon find themselves producing youth who cannot survive nor compete in the very near future."

Nigeria being a developing African country also was hard hit by the COVID-19 pandemic. Prior to COVID-19, Nigeria was on a struggle to ensure young children stay in school and have access to proper education, as about 10.5 million of the country's children are out of school such that Nigeria contributes approximately $20 \%$ of the total global out-of-school population [17]. Now, the lockdown imposed by the government for at least four months in every state in the country which though was imperative added insult to injury of the Nigerian education sector. However, every country in the world is combating the education challenge through electronic education such that the COVID-19 pandemic is now revolutionizing digital and online education globally but kids in rural and underserved communities including Nigeria, seems to be left behind as they are not equipped to adapt or transit to the new methods of learning. Thus, this study seeks to assess how (positively or negatively) coronavirus outbreak has affected the demand for and adoption of mobile and electronic education in rural and underserved communities in Nigeria using New Bussa, Niger state as case study.

Different research findings have been carried out on the level of ICT usage in the education sector before and during coronavirus pandemic in Nigeria. [6] carried out correlation research design on application of ICT and pointed out the need for tertiary institutions in River state in Nigeria to adopt the ICT applications and resources over the traditional classroom teaching methods to curb the COVID-19 threats to the academic system.

[18] assessed Adoption of E-Learning and M-Learning during Covid-19 Lockdown in Nigeria. Data were collected via communication with students and teachers using random sampling technique via text messages, voice call, social media interaction (whattsapp). Majority of the sampled population are vulnerable to limited or no connection to internet with their mobile phone due to their location during lockdown. The Authors' experience with the students during only teaching using WhatsApp platform revealed that students living in urban area or city enjoy better internet connection compare to those living in the rural areas. They concluded that the students and teachers were willing to accept and explore e-learning and M-learning in schools for teaching and learning while the resources and other facilities to be provided by school management and government are not readily available.

[5] carried out a study on Online and Remote Learning in Higher Education Institutes: A Necessity in light of COVID-19 Pandemic. The research examined how teaching and learning can still continue in educational institutions during novel coronavirus which brings closure to institutions. Findings from the study revealed that universities worldwide are moving more and more towards electronic education. The study further identified important factors that encourage or discourage electronic education including income availability, data access cost, staff readiness, confidence, students' accessibility and motivation. However, the study did not conclude whether or not electronic education was significantly adopted.

[7] carried out a study on COVID-19 and e-Learning: Nigeria Tertiary Education System Experience. The study was necessitated by the expectation that COVID-19 pandemic would shape a new normal for the higher education sector in Nigeria even though E-learning is still confronted with a lot of challenges in Nigerian Universities before the pandemic. The study concluded that e-Learning was not adequately adopted in especially public university due to challenges of e-learning in Nigeria which ranges from irregular power supply, high internet subscription costs, poor internet access. 


\section{Material and Method}

This study employed survey design. At the inception of the study, a checklist of popular proprietary e-education applications and some popular social media software applications in Nigeria that can support electronic education was obtained and the survey was designed based on the checklist obtained.

\subsection{Materials}

The study was conducted during the corona virus outbreak, at the time when many organizations are just allowed to resume work and when many schools (especially tertiary institutions of learning) are still yet to resume physical classes. Furthermore, a protest (codenamed EndSARS youth protest) which causes further curfew to be imposed in some parts of the country ensued. As such, the study employed an online survey in which social media contacts of the researchers that carried out this study were included in the study without any exclusion criteria. However, only contacts that desire to be parts of the study were followed up. The research instrument was a self-constructed electronic education adoption questionnaire. The questionnaire consists of sections $\mathrm{A}-\mathrm{E}$, section ' $\mathrm{A}$ ' collects information about the demographic characteristics of the respondents while section ' $\mathrm{B}$ ' consists of awareness about the existence of relevant software while section ' $C$ ' and ' $D$ ' collect information about level of usage of itemised software before and during the corona virus outbreak while section E collect information about purpose of usage of the various software resources.

\subsection{Experimental Process}

The self-constructed questionnaire was inputted into Google form and the website link to access the Google form was sent via social media to contacts of all researchers that carried out the study. Daily follow up messages were sent to the prospective respondents within two weeks. The Google form was made accessible to participants between $18^{\text {th }}$ of October and $10^{\text {th }}$ of November, 2020. At the end of the set duration, a total number of one hundred and sixty (160) responses were retrieved. Some of the questionnaires were open-ended questions while some are in various point Likert scales and others are in grading scales questions. Interview of randomly administrators of some schools about their provisioning of electronic education to their students during the lockdown also provides data to support data gotten through the online survey.

\subsection{Method of Data Analysis}

The data collected from the participants were analysed using charts, descriptive statistics (frequencies and percentages, means), paired sample and independent sample T-Test statistics with the aid of Microsoft Excel and Statistical Package for Social Sciences (SPSS).

Results obtained in sections ' $C$ ', ' $D$ ' and ' $E$ ' were analysed using t-test statistics to achieve research objectives while sections ' $A$ ' and ' $B$ ' analysed using descriptive statistics and multiple response analysis serve to concretise the results obtained in analysing sections ' $C$ ', ' $D$ ' and ' $E$ '.

\section{Results and Discussion}

\subsection{Results}

Tables 1 and 2 described the personal data of the respondents. Responses presented in table 1 shows that $69.4 \%$ of the respondents were males while the female respondents were just 30.6\%. The respondents possessed various educational qualifications even though the highest percentage of them had Bachelors' degree (35.6\%), national diploma $(20.0 \%)$ is next, $18.1 \%$ possessed Masters' degree, only 10\% had higher national diploma certificate, and as low as 5.6\% had national certificate in education as their highest qualification, $3.8 \%$ had senior secondary certificate, $3.8 \% \mathrm{had} \mathrm{PhD}$, the remaining $3.1 \%$ possessed only first leaving certificate while there was no respondent that has not gone through at least primary education.

In table 2, the age, income and internet access value mean distribution of the respondents were presented. The respondents were shown to fall between the age bracket of sixteen (16) and fifty six (56) while the average age was found to be approximately 31 years old and $55 \%$ of the respondents are less than 31 years. The respondents' monthly internet data access fell between zero (0) and seventy thousand megabytes $(70000 \mathrm{MB})$ while the average data access was approximately four thousand, eight hundred and fifty megabytes (4834.29MB that is, $4.85 \mathrm{~GB})$ and $65 \%$ of the respondents use less than $4.85 \mathrm{~GB}$ data every month. The respondents' monthly income fell between zero (0) and three hundred thousand ( $\$ 300,000.00)$ while the average income was approximately fifty thousand naira $(\$ 50,000.00)$ and $74.4 \%$ of the respondents earn less $\$ 50,000$. The average income was used as income divide in table 9. 
Table 1. Frequency distribution of respondents by gender, marital status and qualifications

\begin{tabular}{|c|c|c|c|}
\hline \multicolumn{2}{|r|}{ Variables } & \multirow[t]{2}{*}{ Frequency } & Percent \\
\hline Gender & Male & & $69.4 \%$ \\
\hline & Female & 49 & $30.6 \%$ \\
\hline \multirow[t]{3}{*}{ Marital Status } & Single & 86 & $53.8 \%$ \\
\hline & Married & 71 & $44.4 \%$ \\
\hline & Divorced & 3 & $1.9 \%$ \\
\hline \multirow[t]{9}{*}{ Qualifications } & Non & 0 & $0.0 \%$ \\
\hline & Primary & 5 & $3.1 \%$ \\
\hline & Secondary & 6 & $3.8 \%$ \\
\hline & National Certificate in Education & 9 & $5.6 \%$ \\
\hline & National Diploma & 32 & $20.0 \%$ \\
\hline & Higher National Diploma & 16 & $10.0 \%$ \\
\hline & Bachelors' Degree & 57 & $35.6 \%$ \\
\hline & Masters' Degree & 29 & $18.1 \%$ \\
\hline & Doctor of Philosophy & 6 & $3.8 \%$ \\
\hline
\end{tabular}

Table 2. Mean distribution of the respondents by age, monthly income and average monthly internet access value

\begin{tabular}{|c|r|r|r|r|r|r|}
\hline & N & Minimum & Maximum & Mean & N<Mean & Std. Deviation \\
\hline Age & 160 & 16 & 56 & 30.81 & $88(55 \%)$ & 8.519 \\
Income & 160 & 0 & 300000 & 49988.04 & $119(74.4 \%)$ & 66892.833 \\
InternetVal & 159 & 0 & 70000 & 4834.29 & $104(65.0 \%)$ & 8873.825 \\
\hline
\end{tabular}

Source: Field study, 2020

Table 3 shows the level of awareness about e-education applications in the study area. It was found that only $38.8 \%$ of the respondents were aware of software (website and mobile) application for electronic education while $42.5 \%$ were not aware of any electronic education software adversely, as much as $80.6 \%$ of the respondents were aware of radio and television broadcast for electronic education while only $4.4 \%$ were not aware of radio and television broadcast for electronic education.

Table 4 shows the level of adoption of social media channels for electronic education. A total of one hundred and nine (125 representing 78.13\%) respondents use one or more social media channel for electronic education. Google search (used by $46.9 \%$ of the respondents), YouTube (used by $45.6 \%$ of the respondents) and WhatsApp (used by $44.4 \%$ of the respondents) were the most used social media and generalised applications adopted to support electronic education while twitter and instagram were the only social media applications whose adoption for electronic education tend to be lowest.

Table 3.Level of awareness about existence of e-education software and television broadcast

\begin{tabular}{|c|c|c|c|c|c|c|}
\hline \multirow{3}{*}{ Variable } & \multicolumn{6}{|c|}{ Responses } \\
\hline & \multicolumn{2}{|c|}{ Yes } & \multicolumn{2}{|c|}{ No } & \multicolumn{2}{|c|}{ Unsure } \\
\hline & $\mathbf{N}$ & Percent & $\mathbf{N}$ & Percent & $\mathbf{N}$ & Percent \\
\hline $\begin{array}{c}\text { e-education website and mobile application } \\
\text { awareness }\end{array}$ & 62 & $38.8 \%$ & 68 & $42.5 \%$ & 30 & $18.8 \%$ \\
\hline e-education satellite television awareness & 129 & $80.6 \%$ & 7 & $4.4 \%$ & 24 & $15.0 \%$ \\
\hline
\end{tabular}

Table 4.Rate of adoption of popular social media channels and/or generalized applications for electronic education

\begin{tabular}{|l|r|r|r|}
\hline \multirow{2}{*}{ Social Media channels } & \multicolumn{2}{|c|}{ Number of Cases (125) } & \multirow{2}{*}{$\begin{array}{c}\text { As percentage of total response } \\
\text { (160) }\end{array}$} \\
\cline { 2 - 4 } & N & Percentage & $30.6 \%$ \\
\hline Facebook & 49 & $39.2 \%$ & $44.4 \%$ \\
\hline WhatsApp & 71 & $56.8 \%$ & $46.9 \%$ \\
\hline Google Search & 75 & $60.0 \%$ & $28.8 \%$ \\
\hline Zoom & 46 & $36.8 \%$ & $21.3 \%$ \\
\hline Skype & 34 & $27.2 \%$ & $13.8 \%$ \\
\hline Twitter & 22 & $17.6 \%$ & $27.5 \%$ \\
\hline Telegram & 44 & $35.2 \%$ & \\
\hline Instagram & 25 & $20.0 \%$ & \\
\hline Youtube & 73 & $58.4 \%$ & \\
\hline
\end{tabular}

The results of statistical analysis presented in tables 5, 6, 7, 8 and 9 serves to test the hypotheses stated. It is to be noted that the mean rating scale of tables $5-9$ is from 1 to 7 . More so, in the analysis presented in table 9, approximate mean salary $(\mathrm{N} 50,000)$ was used as the monthly income divide based on the results presented in table 2. 
Research Objective 1: To examine the difference in adoption of electronic education software resources before and during coronavirus pandemic

To achieve objective 1, table 5 shows the difference in rate of adoption of electronic education through software resources (website and mobile app.) before and during coronavirus outbreak.

Table 5.Level of adoption of electronic education through software (website and mobile app) before and during coronavirus outbreak

\begin{tabular}{|l|c|c|c|}
\hline Variables & Mean & Mean difference & p-value \\
\cline { 1 - 3 } App_Education_use_before & 3.72 & \multirow{2}{*}{0.181} & \multirow{2}{*}{0.223} \\
\hline App_Education_use_during & 3.90 & & \\
\hline
\end{tabular}

Research Objective 2: To analyse the difference in adoption of electronic education through radio/television broadcast before and during coronavirus pandemic

To achieve objective 2, table 6 shows the difference in rate of adoption of electronic education through radio/television resources before and during coronavirus outbreak.

Table 6. Level of adoption of electronic education (through radio and television) before and during coronavirus outbreak

\begin{tabular}{|l|c|c|c|}
\hline Variables & Mean & Mean difference & p-value \\
\cline { 1 - 2 } TV_Education_use_before & 4.53 & \multirow{2}{*}{0.30} & \multirow{2}{*}{0.03} \\
\cline { 1 - 2 } TV_Education_use_during & 4.83 & \\
\hline
\end{tabular}

Research Objective 3: To ascertain the difference between adoption of software resources and radio/television broadcast for electronic education before coronavirus pandemic in the study area

In testing objective 3, table 7 shows the difference in rate of adoption of electronic education through software resources and radio/television resources before coronavirus outbreak.

Table 7. Comparative analysis of adoption of electronic education through television and through software (website and mobile app) BEFORE coronavirus outbreak

\begin{tabular}{|l|c|c|c|}
\hline \multicolumn{1}{|c|}{ Variables } & Mean & Mean difference & p-value \\
\hline App_Education & 3.72 & \multirow{2}{*}{0.806} & \multirow{2}{*}{0.00} \\
\hline TV_Education & 4.53 & & \\
\hline
\end{tabular}

Research Objective 4: To ascertain the difference between adoption of software resources and radio/television broadcast for electronic education during coronavirus pandemic in the study area

In testing objective 4 , table 8 shows the difference in rate of adoption of electronic education through software resources and radio/television resources during coronavirus outbreak.

Table 8. Comparative analysis of adoption of electronic education through television and through software (website and mobile app) DURING coronavirus outbreak

\begin{tabular}{|l|c|c|c|}
\hline \multicolumn{1}{|c|}{ Variables } & Mean & Mean difference & p-value \\
\cline { 1 - 2 } App_Education & 3.90 & 0.93 & 0.00 \\
\hline TV_Education & 4.83 & 0.93 \\
\hline
\end{tabular}

Research Objective 5: To determine the influence of income on the adoption of electronic education software in the study area

In testing objective 5, table 9 show effects of income level on adoption of electronic news software resources before and after coronavirus outbreak.

Table 9. Effects of income on adoption of electronic education before and during coronavirus outbreak in Nigeria

\begin{tabular}{|c|c|c|c|c|c|}
\hline & Income & $\mathrm{N}$ & Mean & Mean difference & p-value \\
\hline \multirow{2}{*}{ eEducation_use_before } & above N50,000 & 50 & 4.26 & \multirow{2}{*}{0.79} & \multirow{2}{*}{0.049} \\
\hline & below N50,000 & 110 & 3.47 & & \\
\hline \multirow{2}{*}{ eEducation_use_during } & above N50,000 & 50 & 4.78 & \multirow{2}{*}{1.28} & \multirow{2}{*}{0.002} \\
\hline & below N50,000 & 110 & 3.50 & & \\
\hline
\end{tabular}

\subsection{Discussion of Findings}

The adoption of electronic education software resources before and during corona virus outbreak presented in table 5 shows just a slight increment in adoption of electronic education during $(\mu=3.90)$ over its adoption before $(\mu=3.72)$ corona virus outbreak in the study area on a rating scale of 1 to 7 . Furthermore, the slight increment in the rate of usage of electronic education during the pandemic as compared with before the pandemic was found to be insignificant $(\Delta \mu>$ 
$0, p>0.05$ ) in the study area. This is further supported by the result presented in table 3 that shows that the numbers of those that are aware of existence of e-education software, website and mobile application (38.8\%) is relatively low. Furthermore, table 4 shows that high percentage of electronic education software resources users rely solely on social media channels as electronic education tools indicated by a large percentage of $78.13 \%$ that uses one or more social media channels to partake in electronic education with Google search (46.9\%), YouTube (45.6\%) and WhatsApp $(44.4 \%)$ leading the social media channel mostly used, this is supported by [16] that reported similar situation in various parts of Africa, [16] went on to cite an example of a Nigerian teacher, Emmanuel reported that he and his colleagues "were trained on how to use WhatsApp, Zoom and other apps to prepare and teach the learners". Carter, a project manager from Liberia said: "We have hosted remote mapping training, shared learning resources via social media and WhatsApp groups, and participated in online learning activities as well". The insignificant usage of electronic education tools contrast to findings from Indonesia that found that online learning which uses internet access becomes popular during the corona virus outbreak reported by [19]. No wonder why Salihu a teacher in Nigeria quoted by [16] said "Even without the Covid-19 it is time to review the curriculum and we should move to adopt the digital curriculum that will enable the system to carry new knowledge as it arrives, as knowledge in this global world is more dynamic."

The results depicted in table 6 shows a higher and significantly different adoption value $(\mathrm{p}<0.05)$ of electronic education through radio and television broadcast during $(\mu=4.83)$ over its adoption before $(\mu=4.53)$ coronavirus outbreak in the study area on a rating scale of 1 to 7 . The report presented in table 3 , further concretize this results because as many as $80.6 \%$ reported that they are aware of electronic education through radio and television broadcast. This supports findings across Africa reported by [16] that "Television and radio were widely seen as the most suitable form of communication at the early learning and primary level".

The result presented in table 3 that level of awareness about e-education television broadcast $(80.6 \%)$ was higher compared with that of software resource $(38.8 \%)$ is concretize results presented in table 7 which shows that before coronavirus outbreak, adoption of electronic education through radio/television $(\mu=4.53)$ was significantly higher than through software (website and mobile app - $\mu=3.72, \mathrm{p}<0.05$ ). Also during coronavirus outbreak, the adoption of electronic education through radio/television $(\mu=4.83)$ was still significantly higher than through software (website and mobile app $-\mu=3.90, \mathrm{p}<0.05)$ as presented in table 8 . This result is similar to findings across Africa reported by [16] that overall, countries that reached agreements with telecom companies, used radio and TV effectively, and distributed materials seem to have been the most successful in ensuring the continuity of education. Algeria has 12 TV channels for children from class I to XII in all subjects. In Botswana, national TV has provided schooling and local telecom companies have distributed content. Such arrangements indicate the importance of partnerships. Furthermore, [16] related that Momodou, a civil servant from Gambia, said "We are running Radio, TV and online distance learning through my office at the Ministry of Basic and Secondary Education. At the tertiary level, online platforms are used by the universities and colleges. As a country we organized various stakeholder meetings as part of planning for introduction of the distance learning initiative. We also organized discussion platforms on TV and Radio to engage the general public..."

In determining whether or not income level, it was shown in table 9 that there was significantly higher demand for electronic education by those who had income above N50,000 as compared with those who earn lesser before and during corona virus outbreak $(\Delta \mu>0 ; \mathrm{p}<0.05)$. More so, table 2 shows that $65 \%$ of the respondents use less than $4.85 \mathrm{~GB}$ data every month and $74.4 \%$ of the respondents earn less $\$ 50,000$. This result implies that inability to afford cost of data is the reason many don't adopt electronic education in the study area. No wonder Christine another teacher from Nigeria quoted by [16] also advice government to "Enter into agreements with internet providers to make all education sites free or at least discounted; Embrace blended learning, dis-aggregate the levels unto more than one platform or LMS, embark on massive capacity building of teachers; make standardised content of pre-tertiary schools available on a dedicated platform, teaching lessons via other medium e.g. TV, radio etc." In fact, these findings may be similar to findings across many parts of Africa according to [16], as such Carter a project manager from Liberia said: "The government needs to build the infrastructure and make it affordable to everyone, particularly the Internet. Once urban and rural communities can have access to an affordable and reliable high speed internet, schools and students alike can easily adopt distance learning technologies, platforms, and systems." And Aboagye a teacher from Ghana also requested of their government that "All schools should have access to internet connectivity; Government should heavily subsidize the cost for data bundle; Government should arrange with mobile telephone companies to make the above two suggestions a reality." Also, Doru, an ICT Specialist in Botswana say: "The cost of personal technology (smartphones, home $\mathrm{Wi}-\mathrm{Fi}$ ) needs to decrease for better adoption of electronic education. Botswana is amongst the top 14 countries with the most expensive data." Income reported as the major determinant of demand for e-education during coronavirus outbreak also supported [[7] that also reported that the high cost of internet data services is a major obstacle to elearning in Nigeria as the internet service required to connect to this e-learning platform sometimes requires a lot of data.

Furthermore, the interview conducted on administrators of many public and private schools shows that all public schools in the study area did not make use of any channel to educate their students while some private schools (including Mainstream Energy Solution Secondary school, Regina Caelli Primary school, National Institute of Freshwater Fishery Technology staff school among others) in the study area confessed they only adopts WhatsApp social media application for electronic education of their students during the coronavirus imposed lockdown, thus the 
reason for insignificant difference in adoption of proprietary electronic education software before and during the pandemic imposed lockdown. Management of Mainstream Energy Solution Secondary school and Regina Caelli Primary school complained that the parents cited cost of data as reason they should adopt WhatsApp which they knew they could be accessed for free or at minimal cost as a result of free access to some generalized software applications and social media channels such as Opera browser, WhatsApp and Facebook provided by mobile data providers to their users during the coronavirus imposed lockdown.

\section{Conclusion}

In this study, the effects of coronavirus outbreak on adoption of electronic education in New Bussa, Niger state, Nigeria was examined. It was found that:

i) The coronavirus outbreak does not contribute significantly to the demand for electronic education through software (mobile and website) application and its adoption in the study area.

ii) Social media platforms and generalized application were found to be the mainly adopted software (mobile and website) application while awareness about electronic education proprietary software was shown to be significantly low

iii) Demand for and adoption of radio and television broadcast was found to be influenced significantly by coronavirus outbreak.

iv) Demand for and adoption of radio and television broadcast was found to be significantly higher compared with software (mobile and website) resources

v) Income (and ultimately high cost of internet on the residents) was found to influence choice of radio and television broadcast over software (mobile and website) resources

The implications of this study is that lecturers and students are ready to accept electronic education for teaching and learning if the internet access resources and other facilities are adequate and affordable. It is therefore recommended that Niger state government and in fact, Nigerian government should implement and/or review ICT policies that will ensure adequate internet facility access to both urban and rural population and at the same time reduce internet access cost so as to provide platform to enable effective adoption of electronic education through mobile and website applications. Also, the government should further improve on electronic education through radio and television broadcast through provisioning of more channels that will focus on electronic education broadcast even after the coronavirus is defeated.

\section{References}

[1] Emuoyibofarhe O. Justice, Adigun J. Olusegun, Emuoyiborfarhe N. Ozichi (2020). "Development and Evaluation of Mobile Telenursing System for Drug Administration", International Journal of Information Engineering and Electronic Business (IJIEEB), Vol.12, No.4, pp. 40-52, 2020. DOI: 10.5815/ijieeb.2020.04.05

[2] UNESCO Institute for Information Technologies in Education (UIITE, 2006). Information and Communication Technology in Special Education. Specialized IITE Training materials

[3] Adigun, J. O., Onihunwa. J. O., Jeje, C. A. and Joshua, D. A. (2019). Effectiveness of Duxbury Braille Translator for Teaching the Visually Impaired Students in Federal College of Education (Special), Oyo, Nigeria. International Journal of Applied Research and Technology. 8(2): $130-138$.

[4] Adigun J. O., Irunokhai E., Onihunwa J., Jeje C. A. and Dada O. S. (2020). Framework for Development of a Web based System for Students' Appraisal on Teaching Performance of Lecturers in Federal College of Wildlife Management, New Bussa, Niger State, Nigeria. International Journal of Computer Applications (0975 - 8887) 176(18)

[5] Wahab Ali (2020), Online and Remote Learning in Higher Education Institutes: A Necessity in light of COVID-19 Pandemic. Canadian Center of Science and Education; Vol. 10, No. 3. Pp.16-25.

[6] Ukata, Philip Festus, Onuekwa, Faith Adanne(2020), Application of ICT Towards Minimizing Traditional Classroom Challenges of Teaching and Learning During Covid-19 Pandemic in Rivers State Tertiary Institutions. International Journal of Education and Evaluation, Vol 6. No. 5, pp.24-29.

[7] Adeoye, I. A.1, Adanikin, A. F.2, Adanikin, A (2020). COVID-19 and E-Learning: Nigeria Tertiary Education System Experience. International Journal of Research and Innovation in Applied Science (IJRIAS) | 5(5).

[8] Beldarrain, Y. (2006), "Distance Education Trends: Integrating New Technologies to Foster Student Interaction and Collaboration," Distance Education, 27(2), 139-153.

[9] Beal, C. R., Walles, R., Arroyo, I., and Woolf, B. P. (2007), "On-Line Tutoring for Math Achievement Testing: A Controlled Evaluation," Journal of Interactive Online Learning, 6 (1), p43.

[10] Onihunwa J., Adigun O., Irunokhai E., Sada Y., Jeje A. Adeyemi O., Adesina O., (2018). Roles of continuous assessment scores in determining the academic performance of computer science students in Federal College of Wildlife Management. American Journal of Engineering Research. 7(5): 07-20

[11] Sosa, G. W., Berger, D. E., Saw, A. T., and Mary, J. C. (2011), "Effectiveness of Computer- Assisted Instruction in Statistics," Review of Educational Research, 81(1), 97-128. 
[12] Adigun, J. O., Irunokhai E., Onihunwa. J. O., Jeje, C. A. and Dada, O. S. (2020). Framework for Development of a Web based System for Students' Appraisal on Teaching Performance of Lecturers in Federal College of Wildlife Management, New Bussa, Niger State, Nigeria. International Journal of Computer Application (0975 - 8887). 176 (18).

[13] Zhou, P. et al. (2020). A pneumonia outbreak associated with a new coronavirus of probable bat origin. Nature 579, 270-273 (2020).

[14] World Health Organization (WHO, 2020). Statement on the second meeting of the international health regulations (2005) emergency committee regarding the outbreak of novel coronavirus (2019-nCoV). Geneva, Switzerland. 2020.

[15] Meshari F. Alwashmi (2020). The Use of Digital Health in the Detection and Management of COVID-19. Int. J. Environ. Res. Public Health 2020, 17, 2906; doi:10.3390/ijerph17082906 retrieved from: http://www.mdpi.com/journal/ijerph

[16] E-learning Africa: EdTech Hub (2020). The Effect of Covid-19 on Education in Africa and its Implications for the Use of Technology: A Survey of the Experience and Opinions of Educators and Technology Specialists. DOI 10.5281/zenodo.4018774

[17] United Nations' International Children Emergency Fund (UNICEF, 2013). The challenge: One in every five of the world's out of school children is in Nigeria. Retrieved from: http://www.unicef.org/nigeria/education On: 26/10/2020

[18] Yekini N.A et al., (2020); Assessment of Adoption of E-Learning and M-Learning during Covid-19 Lockdown in Nigeria . Int Aca J Edu Lte.1 (1) 28-34.

[19] Henny Yulia (2020). Online Learning to Prevent the Spread of Pandemic Corona Virus. English Teaching Journal. ETERNAL 11(1). Available at: http://journal.upgris.ac.id/index.php/eternal/index

\section{Authors' Profiles}

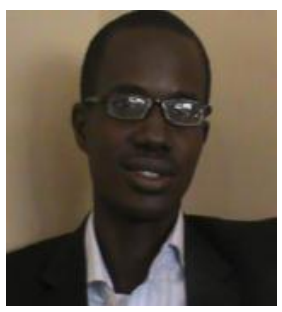

Joseph O. ADIGUN studied Computer Science and Engineering with specialization in Computer Science and graduated with a BTECH (Hons) from Ladoke Akintola University of Technology in 2008, obtained a Masters' degree (Mtech., Computer Science) from the same university in 2018. He has had work experience with Forestry Research Institute of Nigeria as a Senior Programme Analyst and is currently a lecturer at the Federal College of Wildlife Management, New Bussa. He had a one year intensive training as a professional teacher at Federal College of Education (Special), Oyo in 2016 and has a Professional Diploma in Special Education. His research interest includes Computer Science special education and Human Computer Interaction with special consideration for Special Education and electronic/mobile health.

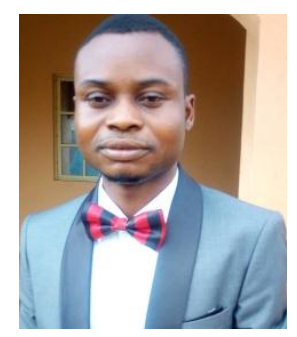

Eric A. IRUNOKHAI studied Computer Science and graduated with a B.Sc. (Hons) from Olabisi Onabanjo University in 2010, obtained a Master's degree in Computer Science from Ahmadu Bello University, Zaria in 2017. He has working experience as a programme analyst with Forestry Research Institute of Nigeria and currently a lecturer at the Federal College of Wildlife Management, New Bussa. Also Trained on Network Support Professional on Comptian and Cisco Certified Network Associate (CCNA). Research interest includes Algorithms, data mining and artificial intelligence.

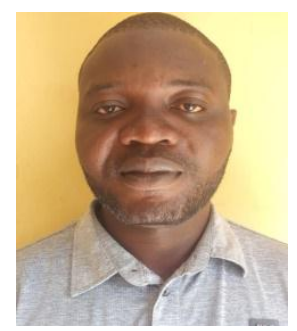

Oluwafemi A. ADENIJI studied Forestry and Wood Technology in Federal University of Technology, Akure, Nigeria and graduated with Second Class Upper Division in 2011, currently on the verge of completing his Master's degree in Forest Resources Management. He has been a Lecturer in the Department of Forestry Technology, Federal College of Wildlife Management, New Bussa, Nigeria, since 2014, his research interests include the following; Forest Mensuration and Inventory, GIS and Remote Sensing in Forestry, Forest Ecology and Environmental Forestry.

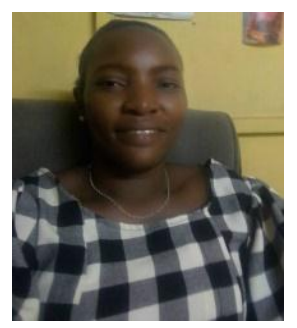

Yetunde Mary AREO is a graduate of University of Ilorin in Educational Technology. She has had work experience with Federal College of Forestry Technology as lecturer and still in the institution. She had three years training as a professional teacher at Oyo State College of Education, Oyo with a Nigeria Certificate in Education. Her research interest is the Entrepreneurial education development in Nigeria. 


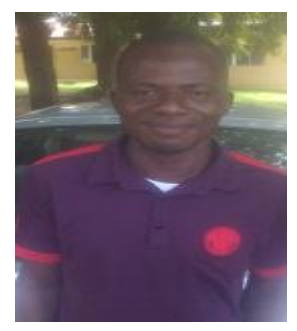

John O. ONIHUNWA studied Mathematics and Computer Science, he graduated with a BTECH (Hons) from Federal University of Technology in 2006, obtained a Masters' degree (MSc., Computer Science) from University of Ibadan in 2015. He has had work experience with Forestry Research Institute of Nigeria as a Senior Programme Analyst and was covered to a lecturer be the institute and is currently a lecturer at the Federal College of Wildlife Management, New Bussa. He is presently pursuing his Doctorate degree (PhD) in Ekiti State University, Ado Ekiti. His research interest includes Database and Internet of Thing (IoT).

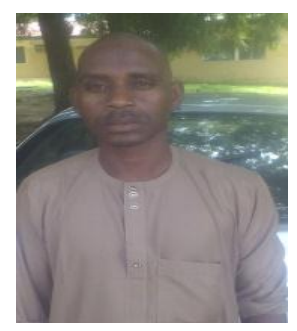

Yusuf A. SADA studied Computer Science and graduated with a BSC (Hons) from Usman Danfodio University, Sokoto in 2006, obtained a Masters' degree (Computer Science) from University of Port Harcourt, Rivers State in 2012. He has had work experience with Forestry Research Institute of Nigeria as a Programme Analyst and is currently a lecturer at the Federal College of Wildlife Management, New Bussa. His research interest includes data mining, Computer network and security.

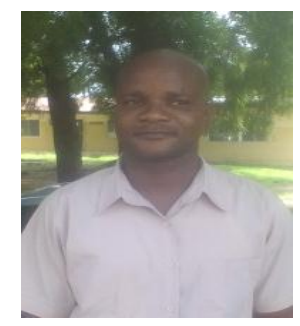

Ayodele C. JEJE graduated from Ekiti state University, Ado-Ekiti. He studied Computer science and graduated with Bsc. (Hons) from the said university in 2010. He is currently on his MSc in the same university. He has been working with Forestry Research Institute of Nigeria as a lecturer and researcher at the Federal College of Wildlife Management New Bussa since 2014. His research interest includes Database and Network security.

How to cite this paper: Joseph O. ADIGUN, Eric A. IRUNOKHAI, Oluwafemi A. ADENIJI, Yetunde M. AREO, John O. ONIHUNWA, Yusuf A. SADA, Caleb A. JEJE, " Role of Coronavirus Outbreak on Adoption of Electronic Education in New Bussa, Niger State, Nigeria", International Journal of Education and Management Engineering (IJEME), Vol.11, No.5, pp. 13-22, 2021. DOI: 10.5815/ijeme.2021.05.02 